\title{
Ratio Decidendi Terhadap Penyalahgunaan Wewenang dalam Tindak Pidana Korupsi (Studi Putusan Nomor: 454/Pid.B/2010/PN.Kdi)
}

\author{
Ratio Decidendi on the Abuse of Authority in Criminal Action of Corruption \\ (Study of Decision No: 454/Pid.B/2010/Pn. Kdi)
}

\author{
Alsabda Liwati \\ Universitas Halu Oleo \\ E-mail: Alsabda.liwati92@gmail.com \\ Sabrina Hidayat \\ Pascasarjana Universitas Halu Oleo \\ E-mail: sabrina.hidayat54@yahoo.com \\ Oheo K. Haris \\ Pascasarjana Universitas Halu Oleo \\ E-mail:oheokh@gmail.com
}

\begin{abstract}
This research is normative legal research. Normative legal research is a process to find a rule of law, legal principles, and legal doctrines in order to answer the legal issues faced. The results of this study indicate that: 1) Verification by the prosecutor that the defendant's actions were illegal because asking for a sum of money in the certificate delivery activities after the activity was carried out was a mistake because in accordance with the cooperation agreement by UNHALU and LPMP, one of the points regarding DIPA was in fact not included in the budget for submitting diplomas held in the Grand Awani building and the cost of legalizing diplomas etc. So that the defendant's actions to announce the payment of a sum of money for the activities of giving certificates and so on are not a violation because they have not been regulated in PP No: 74 of 2008 concerning Teachers, for which prosecutors cannot be proven. 2) The panel of judges gave a free verdict to the defendant from all prosecutors' charges as stated in the judge's ruling which stated: Declare the defendant Nana Sumarna, S.Pd. M.Kes. not proven legally and convincingly guilty of committing a crime in the Primary, Subsidary and More Subsidiary charges; and Freeing Defendant Nana Sumarna, S.Pd. M.Kes. therefore, from the indictments (Vrijspraak); and Restoring the rights of defendants in their capacity, position and dignity; because the prosecutor cannot present evidence or information that can convince the judge that the defendant has committed a criminal act of corruption.
\end{abstract}

Keyword: ratio decidendi; use of authority; Corruption Crime 


\begin{abstract}
Abstrak: Tujuan penelitian dalam penelitian ini adalah: 1) Untuk mengetahui dan menganalisis pembuktian tindak pidana korupsi penyalahgunaan kewenangan pada Putusan Nomor: 454/Pid.B/2010/PN.Kdi. 2) Untuk mengetahui dan menganalisis, ratio decidendi hakim dalam menjatuhkan vonis bebas terhadap terdakwa pada Putusan Nomor: 454/Pid.B/2010/PN.Kdi).

Penelitian ini merupakan penelitian hukum normatif. Penelitian hukum normatif adalah suatu proses untuk menemukan suatu aturan hukum, prinsip-prinsip hukum, maupun doktrin-doktrin hukum guna menjawab isu hukum yang dihadapi. Hasil penelitian ini menunjukkan bahwa: 1) Pembuktian oleh jaksa bahwa perbuatan terdakwa merupakan perbuatan melawan hukum karena meminta sejumlah uang dalam kegiatan penyerahan sertifikat setelah kegiatan terlaksana merupakan sebuah kekeliruan karena sesuai dengan perjanjian kerja sama oleh pihak UNHALU dan LPMP yang salah satu poinnya mengenai DIPA pada kenyataannya tidak masuk dalam anggaran untuk penyerahan ijazah yang dilaksanakan di gedung Grand Awani serta biaya legalisasi ijazah dll. Sehingga perbuatan terdakwa mengumumkan pembayaran sejumlah uang untuk kegiatan penyerahan sertifikat dan lain sebagainya bukan merupakan sebuah perbuatan yang melanggar karena belum diatur dalam PP No: 74 tahun 2008 tentang Guru, untuk itu dakwaan jaksa tidak dapat dibuktikan. 2) Majelis hakim memberikan vonis bebas terhadap terdakwa dari segala dakwaan jaksa seperti disebutkan dalam amar putusannya majelis hakim yang menyatakan: Menyatakan terdakwa Nana Sumarna ,S.Pd. M.Kes. tidak terbukti secara sah dan meyakinkan bersalah Melakukan tindak pidana dalam dakwaan Primer, Subsider dan Lebih Subsider; dan Membebaskan terdakwa Nana Sumarna, S.Pd. M.Kes. oleh karena itu dari dakwaan-dakwaan tersebut (Vrijspraak); serta Memulihkan hak terdakwa dalam kemampuan, kedudukan dan harkat serta martabatnya; disebabkan jaksa tidak dapat menghadirkan bukti maupun keterangan yang dapat meyakinkan hakim bahwa terdakwa telah melakukan tindak pidana korupsi.
\end{abstract}

Kata kunci: ratio decidendi; penyalahgunaan wewenang; Tindak Pidana Korupsi

\title{
PENDAHULUAN
}

Korupsi bukanlah suatu hal yang asing bagi setiap kalangan masyarakat di dunia. Bahkan hal ini merupakan masalah terbesar di Negara-negara berkembang seperti Indonesia. Korupsi sepertinya sudah menjadi budaya yang berkembang di kalangan masyarakat kelas atas sampai bawah. Korupsi dapat dilihat dengan mata telanjang di berbagai institusi, baik eksekutif, legislatif dan yudikatif. Parahnya hampir semua pejabat-pejabat tinggi Negara melakukannya, tanpa mereka pikirkan bahwa tindakan ini merugikan Negara itu sendiri. Hal ini menunjukkan bahwa nilai luhur suatu individu atau yang sering disebut moral mengalami penurunan. Tidak adanya kesadaran seorang individu tentang etika dan aturan hukum yang berlaku membuat korupsi semakin meningkat. Akan tetapi tidak hanya moral individu itu saja yang dapat mempengaruhi terjadinya korupsi, banyak hal yang menjadi 
latar belakang korupsi salah satunya seperti kekuasaan, yang dikenal sebagai abuse of power atau penyalahgunaan kekuasaan. ${ }^{1}$

Tanpa disadari, korupsi muncul dari kebiasaan yang dianggap lumrah dan wajar oleh masyarakat umum. Seperti memberi hadiah kepada pejabat/pegawai negeri atau keluarganya sebagai imbal jasa sebuah pelayanan. Kebiasaan itu dipandang lumrah dilakukan sebagai bagian dari budaya ketimuran. Selama ini kosa kata korupsi sudah popular di Indonesia. Hampir semua orang pernah mendengar kata korupsi. ${ }^{2}$

Regulasi tentang mengatur mengenai tindak pidana korupsi di Indonesia telah memadai dan mengandung materi dan spirit pemberantasan korupsi yang sangat tinggi, namun regulasi yang cukup memadai dan kuat tidaklah cukup untuk memberantas korupsi di tengah praktik korupsi di negeri ini yang semakin banyak terjadi. Praktik korupsi di negeri ini sudah berlangsung sistematis dengan menggunakan modus konvensional sampai dengan modus super canggih. Karena itu, sangat dibutuhkan para aparat penegak hukum, mulai kepolisian, kejaksaan, sampai pengadilan yang memiliki spirit pemberantasan korupsi yang tinggi dan memiliki pemahaman dan penerapan hukum yang progresif. ${ }^{3}$

Salah satu tipe korupsi yang bersumbangsih besar dalam terjadinya peningkatan tindak pidana korupsi adalah tindak pidana korupsi penyalahgunaan kewenangan, Tipe ini tercantum pada Pasal 3 Undang-Undang Nomor 31 Tahun 1999 sebagaimana diubah dan diperbaharui dengan Undang-Undang Nomor 20 Tahun 2001 Tentang Perubahan Atas Undang-Undang Nomor 31 Tahun 1999 Tentang Pemberantasan Tindak Pidana Korupsi (PTPK). ${ }^{4}$

Penyalahgunaan kewenangan menurut Lilik Mulyadi, dapat diartikan dalam 3 (tiga) wujud, yaitu:

1. Penyalahgunaan kewenangan untuk melakukan tindakan-tindakan yang bertentangan dengan kepentingan umum atau untuk menguntungkan kepentingan pribadi, kelompok atau golongan;

1 Murtir Jeddawi, Negara Hukum, Good Governance dan Korupsi di Daerah, Yogyakarta: Total Media, 2011, hlm. 27.

2 Ibid.

3 Ibid.

4 Lilik Mulyadi, Tindak Pidana Korupsi di Indonesia Normatif, Teoritis, Praktik dan Masalahnya. Bandung: PT. Alumni, 2011, hlm. 51. 
2. Penyalahgunaan kewenangan dalam arti bahwa tindakan pejabat tersebut adalah benar ditujukan untuk kepentingan umum, tetapi menyimpang dari tujuan kewenangan yang diberikan oleh undang-undang atau peraturanperaturan lainnya;

3. Penyalahgunaan kewenangan dalam arti menyalahgunakan prosedur yang seharusnya dipergunakan untuk mencapai tujuan tertentu, tetapi telah menggunakan prosedur lain agar terlaksana. ${ }^{5}$

Penyalahgunaan wewenang dianggap sama dengan unsur melawan hukum. Seperti diketahui bahwa Unsur "melawan hukum" merupakan "genus"-nya, sedangkan unsur "penyalahgunaan wewenang" adalah "species"-nya. "Penyalahgunaan wewenang" subjek deliknya adalah pegawai negeri atau pejabat publik, berbeda dengan unsur "melawan hukum" subjek deliknya setiap orang. ${ }^{6}$

Dalam konsep hukum, setiap pemberian wewenang kepada suatu badan atau kepada pejabat administrasi negara selalu disertai dengan "tujuan dan maksud" diberikannya wewenang itu, sehingga penerapan wewenang itu harus sesuai dengan "tujuan dan maksud“ diberikannya wewenang itu. Dalam hal penggunaan wewenang tersebut tidak sesuai dengan "tujuan dan maksud" pemberian wewenang itu maka telah melakukan penyalahgunaan wewenang ("detour nement de pouvoir"). Parameter "tujuan dan maksud“ pemberian wewenang dalam menentukan terjadinya penyalahgunaan wewenang dikenal dengan asas spesialitas. Secara substansial asas spesialitas mengandung makna bahwa setiap kewenangan memiliki tujuan tertentu. ${ }^{7}$

Tindak pidana penyalahgunaan kewenangan dengan tujuan menguntungkan diri sendiri dapat dilihat dalam Perkara putusan nomor: 454/Pid.B/2010/PN.Kdi atas nama terdakwa Nana Sumarna, S.Pd., M.Kes., yang dituntut oleh jaksa karena melakukan perbuatan tindak pidana korupsi seperti yang disebutkan dalam Undang-undang Nomor 20 tahun 2001 Tentang Perubahan Atas Undang-Undang Nomor 31 Tahun 1999 Tentang Pemberantasan Tindak Pidana Korupsi, karena perbuatan terdakwa menurut jaksa penuntut "Secara melawan hukum melakukan perbuatan memperkaya diri sendiri atau

$5 \quad$ Ibid., hlm. 52

6 P.A.F. Lamintang dan Theo Lamintang, Kejahatan Jabatan dan Kejahatan Jabatan Tertentu Sebagai Tindak Pidana Korupsi, Jakarta: Sinar Grafika. 2009, hlm. 61.

7 Ibid., hlm. 63. 
orang lain atau suatu korporasi yang dapat merugikan keuangan negara atau perekonomian negara. ${ }^{8}$

Pada perkara tersebut, jaksa penuntut umum menyebutkan dalam surat dakwaannya bahwa "terdakwa menguntungkan diri sendiri atau orang lain secara melawan hukum, atau dengan menyalahgunakan kekuasaannya memaksa seseorang memberikan sesuatu atau membayar, atau menerima pembayaran yang seharusnya perbuatan terdakwa tidak dilakukan karena pembiayaan kegiatan penilaian sertifikasi guru oleh Universitas Halu Oleo sebagaimana dimaksud dalam surat/pengumuman tertulis telah dianggarkan oleh negara yang kemudian di buat dalam surat Nomor: 1058a/F./F41/2008/1125a/H29/2008.

Akan tetapi dari fakta-fakta yang terungkap dalam persidangan baik itu bukti-bukti yang dihadirkan jaksa penuntut umum, keterangan saksi dan keterangan ahli serta audit BPKP menurut majelis hakim upaya terdakwa meminta pembayaran sejumlah uang kepada para peserta (guru yang mengikuti uji sertifikasi) dengan menggunakan kewenangannya sebagai panitia penyelenggara untuk membiayai biaya sertifikat (penulisan, pengesahan, pengelolaan) dan pengeluaran saat penerimaan sertifikat (konsumsi peserta, akomodasi dan perjalanan tim PSG, pengelolaan) yang akan dilaksanakan di gedung Grand Awani tidak tersedia dalam anggaran penyelenggaraan kegiatan tersebut.

Hakim Pengadilan Negeri Kendari yang berwenang memeriksa perkara tersebut, telah menjatuhkan putusan yang pada intinya menerangkan bahwa perbuatan terdakwa tidak terbukti secara sah dan meyakinkan karena beberapa unsur yang dimaksudkan dalam undang-undang tindak pidana korupsi tidak terpenuhi seperti unsur perbuatan melawan hukum, unsur memperkaya diri sendiri sehingga majelis memberikan vonis bebas dan lepas dari segala tuntutan atau dakwaan.

Sehubungan dengan permasalahan yang telah diuraikan, di atas maka penulis tertarik untuk melakukan penelitian lebih lanjut, mengenai alasan-alasan pertimbangan majelis hakim dalam memberikan vonis bebas serta seperti apakah proses pembuktian dalam perkara tersebut, dengan judul "Ratio Decidendi Terhadap Penyalahgunaan Wewenang Dalam Tindak Pidana Korupsi (Studi Putusan Nomor: 454/Pid.B/2010/PN.Kdi)."

8 Analisa penulis, dalam surat dakwaan jaksa penuntut umum pada Putusan Nomor: 454/Pid.B/2010/PN.Kdi 


\section{METODE PENELITIAN}

Tipe penelitian yang penulis gunakan dalam penelitian adalah penelitian normatif. Adapun pendekatan yang penulis gunakan dalam penelitian ini adalah pendekatan perundang-undangan (statute approach), pendekatan kasus (case approach) dan pendekatan konsep. Teknik pengumpulan bahan hukum yang mendukung dan berkaitan dengan pemaparan penelitian ini adalah studi dokumen (studi kepustakaan), yang dilakukan dengan cara meneliti bahan-bahan pustaka atau data sekunder yang terdiri dari bahan hukum primer, bahan hukum sekunder dan bahan hukum tertier.

\section{ANALISIS DAN PEMBAHASAN}

\section{Pembuktian Tindak Pidana Korupsi Penyalahgunaan Kewenangan Pada Putusan Nomor: 454/Pid.B/2010/PN.Kdi)}

Undang-Undang pemberantasan korupsi di Indonesia, pada era reformasi ini. Contoh kongkretnya dalam reformasi perundang-undangan di Indonesia setelah diterbitkannya Undang-Undang nomor 31 tahun 1999 baru berlaku selama tidak lebih 2 (dua) tahun telah terasa memiliki kelemahan dan kekurangan sehingga terasa harus di perbaharui kembali dengan UU nomor 20 tahun 2001 tentang pemberantasan tindak pidana korupsi. Fakta ini menunjukkan kebenaran pendapat Satjipto Raharjo yang menyatakan bahwa hukum (Undang-Undang) selalu dalam proses menjadi, artinya tidak akan pernah tercipta Undang-Undang yang sempurna sejak lahirnya. ${ }^{9}$

Di dalam Undang-Undang Tidak Pidana Korupsi terdapat tiga (3) istilah hukum yang perlu diperjelas, yaitu istilah tindak pidana korupsi, keuangan negara dan perekonomian negara. Yang dimaksud dengan Tindak Pidana Korupsi sesuai Pasal 2 dan 3 Undang-Undang No. 31 tahun 1999, adalah:

1. Setiap orang yang secara melawan hukum melakukan perbuatan memperkaya diri sendiri atau orang lain atau suatu korporasi yang dapat merugikan keuangan negara atau perekonomian negara.

2. Setiap orang yang dengan tujuan menguntungkan diri sendiri atau orang lain atau suatu korporasi, menyalahgunakan kewenangan, kesempatan atau sarana

9 Abdullah H,. Membangun Gerakan Antikorupsi Dalam Perspektif Pengadilan, Yogyakarta: LP3 UMY, 2011, hlm. 63 
yang ada padanya karena jabatan atau kedudukan yang dapat merugikan keuangan negara atau perekonomian negara. 10

Sedangkan keuangan negara dalam undang-undang ini adalah Seluruh kekayaan negara dalam bentuk apa pun baik yang dipisahkan maupun yang tidak dipisahkan, termasuk di dalamnya segala bagian kekayaan negara dan segala hak dan kewajiban yang timbul karenanya: ${ }^{11}$

Ungkapan melawan hukum dalam tindak pidana korupsi dapat pula mencakup perbuatan-perbuatan tercela yang menurut perasaan keadilan masyarakat harus dituntut dan dipidana. Perbuatan melawan hukum di sini mencakup perbuatan melawan hukum dalam arti formal maupun materiil yakni meskipun perbuatan tersebut tidak diatur dalam peraturan perundang-undangan, namun apabila perbuatan tersebut dianggap tercela karena tidak sesuai dengan rasa keadilan atau norma kehidupan sosial dalam masyarakat, maka perbuatan tersebut dapat dipidana sesuai dengan Pasal 2 ayat 1.12

Tindak pidana korupsi dalam undang-undang ini dirumuskan secara tegas sebagai tindak pidana formal, hal ini sangat penting untuk pembuktian. Dengan rumusan formal yang dianut dalam undang-undang ini berarti meskipun hasil korupsi telah dikembalikan kepada negara, pelaku tindak pidana korupsi tetap diajukan ke Pengadilan dan tetap dipidana. Pengembalian kerugian negara atau perekonomian negara tersebut hanya merupakan salah satu faktor yang meringankan pidana bagi pelakunya. ${ }^{13}$

Sejalan dengan penjelasan pada teori di atas, berdasarkan apa yang tertera dalam putusan Pengadilan Negeri Kendari (Nomor: 454/Pid.B/2010/Pn.Kdi) pembuktian adanya sebuah tindak pidana korupsi dilakukan jaksa penuntut umum dengan hadirnya alat bukti surat, keterangan saksi dan keterangan saksi ahli, sementara pembuktian adanya kerugian negara dari hasil audit BPKP tidak ditemukan adanya penyimpangan.

Pada prosesnya pembuktian oleh jaksa diawali dengan adanya dakwaan yang disebutkan dalam dakwaan primer bahwa: Perbuatan terdakwa sebagaimana diatur dan diancam pidana dalam pasal 12 huruf e Undang-undang Nomor 20 tahun 2001 tentang Perubahan atas Undang-Undang Nomor 31 tahun 1999 tentang Pemberantasan Tindak Pidana Korupsi Jo pasal 55 ayat 1 ke-1 KUHP. Sedangkan pada dakwaan subsider

10 Ibid.

11 Nyoman Jaya S, Tindak Pidana Korupsi, Kolusi, dan Nepotisme di Indonesia, Semarang: Universitas Diponegoro. 2005, hlm. 52

12 Ibid., hlm. 59

13 Krisna Harahap, Pemberantasan Korupsi di Indonesia Jalan Tiada Ujung, Bandung: Grafitri, 2009, hlm. 60 
disebutkan bahwa: Perbuatan terdakwa sebagaimana diatur dan diancam pidana dalam pasal 2 ayat (1) jo. Pasal 18 Undang-undang Nomor 31 tahun 1999 tentang Pemberantasan tindak Pidana Korupsi sebagaimana telah diubah menjadi Undang-Undang Nomor 21 Tahun 2001 tentang Pemberantasan Tindak Pidana Korupsi Jo Pasal 55 ayat (1) ke-1 KUHP.

Adapun dalam dakwaan jaksa penuntut umum pada dakwaan Lebih Subsider disebutkan bahwa: Perbuatan terdakwa sebagaimana diatur dan diancam pidana dalam Pasal 3 Undang-undang Nomor 20 tahun 2001 tentang Pemberantasan Tindak Pidana Korupsi jo. Pasal 18 ayat (1) Undang-Undang Republik Indonesia Nomor 31 tahun 1999 tentang Pemberantasan Tindak Pidana Korupsi jo. Pasal 55 ayat (1) ke-1 KUHP;

Pada prosesnya pembuktian oleh jaksa diawali dengan pembuktian apa yang disebutkan dalam dakwaan primer. Berdasarkan bukti-bukti yang di hadirkan dalam persidangan jaksa tidak dapat membuktikan terpenuhinya seluruh unsur-unsur tindak pidana yang disebutkan dalam undang-undang tindak pidana korupsi. Akan tetapi ada juga unsur dalam dakwaan yang terbukti kebenarannya.

Berdasarkan dakwaan yang disebutkan dalam dakwaan primer pada intinya dikatakan bahwa terdakwa: "Pegawai Negeri atau penyelenggara Negara yang dengan maksud menguntungkan diri sendiri atau orang lain secara melawan hukum, atau dengan menyalahgunakan kekuasaannya memaksa seseorang memberikan sesuatu, membayar, atau menerima pembayaran dengan potongan, atau untuk mengerjakan sesuatu bagi dirinya sendiri"

Menurut penulis berdasarkan pembuktian di persidangan dengan apa yang disebutkan dalam dakwaan primer maka jaksa hanya dapat membuktikan bahwa terdakwa Nana Sumarna, S.Pd,M. Kes., benar adalah seorang pegawai negeri sipil tidak bisa terbantahkan oleh majelis hakim karena terdakwa yang merupakan Pegawai Negeri Sipil (PNS) berdasarkan Surat Keputusan (SK) Menteri Pendidikan dan Kebudayaan Republik Indonesia Nomor:162c/SK/42.H15/C/1995 yang ditugaskan sebagai Sekretaris dalam susunan Panitia Sertifikasi Guru (PSG) berdasarkan SK Rektor UNHALU Nomor:240A/SK/H29/PP/2008, yang kemudian ditunjuk sebagai Ketua Pelaksana berdasarkan Surat Tugas, Nomor: 199a/H29.1/2009, tanggal 06 Mei 2009, yang ditandatangani oleh Dekan FKIP Drs. H. Barlian, M.Pd. (Penanggung jawab Pelaksana dalam susunan PSG/Ketua Pelaksana Rayon 26) 
Sedangkan pembuktian oleh jaksa penuntut umum adanya unsur “Dengan maksud menguntungkan diri sendiri atau orang lain“ yang dilakukan oleh terdakwa yaitu bermula saat terdakwa Nana Sumarna, S.Pd., M.Kes. selaku Sekretaris dalam susunan Panitia Sertifikasi Guru (PSG) yang kemudian ditunjuk sebagai Ketua Pelaksana berdasarkan Surat Tugas, Nomor:199a/H29.1/2009, tanggal 06 Mei 2009, tidak tetap didakwakan kepada terdakwa Nana Sumarna, S.Pd, M.Kes., karena dalam pelaksanaan kegiatan sertifikasi yang dilaksanakan tidak ada keuntungan yang didapatkan oleh terdakwa.

Penulis melihat, pada kenyataannya pengumuman secara tertulis kepada para peserta/guru penerima sertifikat pendidikan untuk melakukan pembayaran atau menyetorkan sejumlah uang, yang pada poin 2 huruf A Surat pengumuman tertulis tersebut menyebutkan bahwa "Biaya sertifikat (Penulisan, pengesahan, pengelolaan, dan lain-lain) sebesar Rp.75.000 (tujuh puluh lima ribu rupiah) per orang dan diterima oleh PSG Rayon 26 UNHALU sebelum penerimaan Sertifikat "dan huruf B menyebutkan“ biaya penerimaan sertifikat disesuaikan dengan pengeluaran saat penerimaan (konsumsi peserta, akomodasi dan perjalanan tim PSG, pengelolaan dll.) dan berhasil memperoleh uang sebesar Rp.36.450.000, (tiga puluh enam juta empat ratus lima puluh ribu rupiah), benar adanya bahwa uang tersebut digunakan sepenuhnya untuk acara kegiatan penyerahan sertifikat tanpa adanya keuntungan yang didapatkan oleh terdakwa pengumpulan dana tersebut.

Dari uraian bukti serta keterangan saksi maupun saksi ahli di dalam persidangan jaksa telah keliru menafsirkan perbuatan terdakwa menyelenggarakan penyerahan sertifikat yang dilaksanakan di gedung Grand Awani, karena dari audit BPKP tidak ditemukan adanya penyimpangan keuangan yang menggambarkan adanya upaya dalam kegiatan penyerahan sertifikat "Dengan maksud menguntungkan diri sendiri atau orang lain“ bahkan dari keterangan saksi 10. Saksi Prof. Dr. Ir. Usman Rianse, MS, yang pada intinya menyebutkan: Bahwa seluruh kegiatan sertifikasi tersebut sudah ada biayanya dari Negara melalui APBN hingga proses sertifikat jadi tetapi untuk penyerahan dan acara penyerahan tidak ada biaya dari DIPA atau APBN; dan saksi 13 saksi ahli Dra. Santi Ambarukmi, M.Ed; yang pada intinya menyebutkan bahwa bagi peserta yang lulus Portofolio maupun PLPG sertifikatnya diserahkan bersama sama dan untuk pembuatan sertifikat sudah masuk dalam APBN sedangkan untuk fotokopi legalisasi tidak ada biaya dari APBN/DIPA; Bahwa untuk Acara penyerahan sertifikat yang diadakan di Gedung 
Grand Awani tidak ada biaya dari APBN/DIPA dan menurut saksi Acara tersebut juga tidak wajib;

Kemudian saksi 9.Saksi Hj. Masnah, S.Ip,; Bahwa saksi adalah PNS pada FKIP Unhalu dan untuk kegiatan Penyelenggaraan sertifikasi guru berdasarkan SK Rektor Unhalu Nomor:290A/SK/H29/PP/2008 tanggal 07 November 2008, saksi sebagai bendahara mengatakan telah ada audit dari BPKP dan tidak ditemukan penyimpangan keuangan. Sehingga Pembuktian bahwa terdakwa melanggar pasal 12 huruf e Undang-Undang Nomor 20 Tahun 2001 tentang Perubahan Atas Undang-Undang Nomor 31 Tahun 1999 tentang Pemberantasan Tindak Pidana Korupsi Jo. Pasal 55 ayat (1) ke-1 KUHP yang unsur-unsurnya adalah sebagai berikut; Pegawai Negeri atau penyelenggara Negara; Dengan maksud menguntungkan diri sendiri atau orang lain Secara melawan hukum, atau menyalah gunakan kekuasaannya; Memaksa seseorang memberikan sesuatu, membayar, atau menerima pembayaran dengan potongan, atau untuk mengerjakan sesuatu bagi dirinya sendiri, tidak terpenuhi unsurnya.

Menurut penulis, unsur "dengan tujuan menguntungkan diri sendiri atau orang lain atau suatu korporasi" ini bersifat alternatif, artinya cukup dengan terbukti salah satu saja dari 3 (tiga) alternatif "menguntungkan" tersebut, yaitu menguntungkan diri sendiri, atau menguntungkan orang lain atau menguntungkan suatu korporasi, maka unsur ini telah terpenuhi.

Mengenai hal tersebut berdasarkan yurisprudensi Mahkamah Agung Republik Indonesia dengan putusannya tertanggal 29 Juni 1989 Nomor: 813 K/Pid/1987 dalam pembuktiannya hukumnya majelis hakim menyatakan antara lain bahwa unsur "menguntungkan diri sendiri atau orang lain atau suatu badan" cukup dinilai dari kenyataan yang terjadi atau dihubungkan dengan perilaku Terdakwa sesuai dengan kewenangan yang dimilikinya karena jabatan atau kedudukan. Untuk itu jika melihat sesuai dengan apa yang telah disebutkan dalam putusan Perkara Nomor: 454/Pid.B/2010/PN.Kdi maka terdakwa tidak layak dikatakan bahwa dalam kegiatan tersebut ada maksud menguntungkan diri sendiri karena faktanya dari beberapa alat bukti perincian penggunaan dana tersebut semuanya terpakai untuk kegiatan penyerahan sertifikat.

Selanjutnya adapun dalam pembuktian adanya unsur "Secara Melawan Hukum" yang di dakwakan oleh jaksa penuntut umum. Menurut penulis, unsur melawan hukum. ini adalah syarat umum dapat dipidananya suatu perbuatan. Sifat melawan hukum 
materiil, Perbuatan melawan hukum materiil (materiel wederrechtelijkheid) adalah perbuatan yang bertentangan dengan aturan hukum tidak tertulis yakni hukum kebiasaan dan rasa keadilan dalam masyarakat serta nilai kepatutan di dalam masyarakat. Melawan hukum menggunakan kewenangan meliputi menggunakan kewenangannya bertentangan dengan hukum tertulis (peraturan perundang-undangan) ataupun hukum tidak tertulis (apabila di dalam hukum administrasi hukum tidak tertulis merupakan asas umum pemerintahan yang baik), akan tetapi melawan hukum di sini tetap berpedoman pada asas legalitas sebagai dasar hukum pidana.

Dalam Perkara Nomor: 454/Pid.B/2010/PN.Kdi, walaupun mengenai penyelenggaraan sertifikasi menurut jaksa dalam penyelenggaraannya tersebut tidak pungut biaya sesuai dengan Pasal 14 Peraturan Pemerintah (PP) Nomor: 74 tahun 2008 tentang Guru Bagian Ketiga, Anggaran Peningkatan Kualifikasi Akademik dan Sertifikasi Pendidik bagi Guru Dalam Jabatan.

Berdasarkan peraturan tersebut di atas, jaksa menyatakan bahwa perbuatan terdakwa merupakan perbuatan melawan hukum karena meminta sejumlah uang dalam kegiatan penyerahan sertifikat setelah kegiatan terlaksana merupakan sebuah kekeliruan karena sesuai dengan perjanjian kerja sama yang disepakati oleh pihak UNHALU dan LPMP yang salah satu poinnya memuat Daftar Isian Pelaksanaan Anggaran (DIPA) pada kenyataannya tidak memasukkan anggaran penyerahan ijazah yang dilaksanakan pada gedung Grand Awani serta biaya legalisasi ijazah dan biaya lainnya.

Menurut penulis berdasarkan penjelasan di atas maka dalam kaitannya pembuktian unsur melawan hukum yang di dakwakan oleh jaksa penuntut dalam Putusan Perkara Nomor:454/Pid.B/2010/PN.Kdi tersebut tidak terpenuhi karena jika melihat fakta yang tertera pada putusan perbuatan yang dilakukan oleh terdakwa untuk mengadakan Acara Penyerahan Sertifikat di gedung Grand Awani dengan cara menarik pembayaran dari guru-guru sebesar Rp.75.000.-yang ditempel di papan pengumuman FKIP Unhalu dengan merinci penggunaan anggaran tersebut untuk biaya-biaya sewa gedung, konsumsi (snack dan makan), fotokopi sertifikat dan legalisasi dan pengelolaan lain adalah untuk kegiatan Acara Penyerahan Sertifikat Guru yang tidak dianggarkan dalam Daftar Isian Pelaksanaan Anggaran (DIPA) sebagaimana juga di jelaskan oleh saksi ahli dalam persidangan untuk itu seharusnya unsur melawan hukum tidak layak didakwakan oleh jaksa terhadap terdakwa. Di samping itu berdasarkan pemahaman 
penulis pada asas legalitas, suatu perbuatan yang secara formal terbukti tidak melawan hukum maka terdakwa tidak boleh dipidana.

Adapun pembuktian dalam dakwaan lebih subsider oleh jaksa yang menyebutkan bahwa perbuatan terdakwa "dapat merugikan negara atau perekonomian negara" menurut penulis sama sekali tidak beralasan karena berdasarkan pada keterangan saksi Hj. Masnah, S.Ip., menyebutkan bahwa telah dilakukan audit BPKP dan tidak ada penyimpangan keuangan negara yang dapat merugikan perekonomian negara, dengan adanya hal tersebut, maka unsur dakwaan subsider oleh jaksa yaitu melanggar Pasal 3 Jo. Pasal 18 Undang-undang Nomor 31 tahun 1999 tentang Pemberantasan tindak Pidana Korupsi sebagaimana telah diubah menjadi Undang-Undang Nomor 20 Tahun 2001 tentang Pemberantasan Tindak Pidana Korupsi Jo. Pasal 55 ayat 1 ke-1 KUHP unsurunsurnya telah terbantahkan dengan sendirinya karena berdasarkan hasil audit BPKP tidak ada penyimpangan keuangan yang dilakukan oleh terdakwa sehingga dakwaan dan tuntutan jaksa penuntut umum tidak terbukti.

\section{Ratio Decidendi Hakim Dalam Menjatuhkan Vonis Bebas Terhadap Terdakwa Pada Putusan No: 454/Pid.B/2010/Pn.Kdi)}

Pertimbangan hakim merupakan salah satu aspek terpenting dalam menentukan terwujudnya nilai dari suatu putusan hakim yang mengandung keadilan (ex aequo et bono) dan mengandung kepastian hukum, di samping itu juga mengandung manfaat bagi para pihak yang bersangkutan sehingga pertimbangan hakim ini harus disikapi dengan teliti, baik, dan cermat. Apabila pertimbangan hakim tidak teliti, baik, dan cermat, maka putusan hakim yang berasal dari pertimbangan hakim tersebut akan dibatalkan oleh Pengadilan Tinggi/Mahkamah Agung. ${ }^{14}$

Hakim tidak dapat menjatuhkan suatu putusan sebelum nyata baginya bahwa peristiwa/fakta tersebut benar-benar terjadi, yakni dibuktikan kebenarannya, sehingga tampak adanya hubungan hukum antara para pihak. Selain itu, pada hakikatnya pertimbangan hakim hendaknya juga memuat tentang hal-hal sebagai berikut:

1. Pokok persoalan dan hal-hal yang diakui atau dalil-dalil yang tidak disangkal.

2. Adanya analisis secara yuridis terhadap putusan segala aspek menyangkut semua fakta/hal-hal yang terbukti dalam persidangan.

14 Tri Andrisman, Hukum Acara Pidana, Lampung: Universitas Lampung, 2010, hlm. 88 
3. Adanya semua bagian dari petitum Penggugat harus dipertimbangkan/diadili secara satu demi satu sehingga hakim dapat menarik kesimpulan tentang terbukti/tidaknya dan dapat dikabulkan/tidaknya tuntutan tersebut dalam amar putusan. ${ }^{15}$

Menurut Malcolm Davies, A jugde who is ready to decide what is justice and for the public weal without any knowledge of history and precedent is an egoist and an ignoranmus artinya seorang hakim yang siap memutus atas nama keadilan kesejahteraan umum wajib memiliki pengetahuan tentang hukum dengan baik maupun pengetahuan tentang yurisprudensi. ${ }^{16}$

Dalam menjatuhkan putusan terhadap suatu perkara, terlebih putusan pemidanaan, hakim harus benar-benar menghayati dan meresapi arti amanat dan tanggung jawab yang diberikan kepadanya sesuai dengan fungsi dan kewenangannya, masing-masing ke arah tegaknya hukum, demi terciptanya tujuan dari hukum itu sendiri yakni keadilan, kemanfaatan, dan kepastian hukum dengan berlandaskan Pancasila dan Undang-Undang Dasar 1945. ${ }^{17}$

Selain pertimbangan yuridis dari delik yang didakwakan, hakim juga harus menguasai aspek teoritis, pandangan doktrin, yurisprudensi, dan posisi kasus yang ditangani, barulah kemudian secara limitatif ditetapkan pendiriannya. Menurut Muhammad Abdulkadir, setelah diuraikan mengenai unsur-unsur delik yang didakwakan, ada tiga bentuk tanggapan dan pertimbangan hakim, antara lain: “Tiga bentuk tanggapan dan pertimbangan hakim yakni: ${ }^{18}$

1. Ada majelis hakim yang menanggapi dan mempertimbangkan secara detail, terperinci, dan substansial terhadap tuntutan pidana dari penuntut umum dan pleidoi dari terdakwa atau penasihat hukum.

2. Ada pula majelis hakim yang menanggapi dan mempertimbangkan secara selintas terhadap tuntutan pidana dari penuntut umum dan pleidoi dari terdakwa atau penasihat hukum.

15 Ibid., hlm. 99

16 Malcolm Davies, Criminal Justice: An Introduction to The Criminal Justice System in England and Wales, London: Pearson Education Limited, 2005, hlm 21.

17 Abdul Manan, Etika Hakim Dalam Penyelenggaraan Peradilan, Jakarta: Kencana Perdana Group, 2008, hlm. 37

18 Muhammad Abdulkadir, Etika Profesi Hakim, Bandung: Citra Aditya Bakti, 2007, hlm. 45 
3. Ada majelis hakim yang sama sekali tidak menanggapi dan mempertimbangkan terhadap tuntutan pidana dari penuntut umum dari pleidoi dari terdakwa atau penasihat hukum."19

Putusan pengadilan setelah diucapkan akan mengikat secara yuridis kepada para pihak yang berperkara dan setiap orang yang disebutkan secara tegas dalam isi putusan dengan tanpa mengurangi hak-hak bagi para pihak untuk mengajukan upaya hukum kepada badan peradilan yang lebih tinggi jika ia merasa tidak puas terhadap isi putusan yang dijatuhkan. Sedangkan secara sosiologis putusan juga mengikat setiap orang, baik secara langsung maupun secara tidak langsung, karena pada hakikatnya dalam setiap putusan yang dijatuhkan tersirat kewajiban bagi setiap orang untuk menghormati isi putusan itu sebagaimana setiap orang diwajibkan untuk menghormati hukum yang berlaku. ${ }^{20}$

Putusan pengadilan merupakan seluruh rangkaian proses pemeriksaan persidangan sampai pada sikap hakim untuk mengakhiri perkara yang disidangkan. Putusan pengadilan tidak dapat dipahami hanya membaca amar putusan, melainkan secara keseluruhan. Formalitas putusan terdiri dari 4 (empat) bagian yaitu kepala putusan, identitas para pihak, pertimbangan dan amar Putusan pengadilan yaitu hasil akhir proses peradilan. Putusan pengadilan merupakan mahkota bagi hakim dan inti mahkotanya terletak pada pertimbangan hukumnya, sedangkan bagi para pencari keadilan pertimbangan hukum yang baik akan menjadi mutiara yang berharga. Pertimbangan hukum putusan merupakan bagian paling penting dalam sistematika putusan karena itu akan mencerminkan bentuk tanggung jawab hakim kepada hukum yang berlaku. Menurut Pasal 193 Kitab Undang-Undang Hukum Acara Pidana (KUHAP), putusan pidana dijatuhkan apabila pengadilan berpendapat bahwa terdakwa bersalah melakukan tindak pidana yang didakwakan kepadanya. ${ }^{21}$

Berdasarkan hasil pemeriksaan di sidang pengadilan dengan bertitik tolak kepada surat dakwaan, pembuktian, musyawarah majelis, dan mengacu pada Pasal 191 ayat (1)

\footnotetext{
19 Ibid., hlm. 46

20 Edy Wibowo, "Peranan Hakim dalam Pencegahan dan Pembrantasan Korupsi”. Jurnal Legislasi Indonesia Volume 7 November 4 Desember 2010, Direktorat Jendral Peraturan Perundang-undangan Kementerian Hukum dan Hak Asasi Manusia RI. hlm. 19

21 Indriyanto Seno Adji, Korupsi dan Penegakan Hukum, Jakarta: Diadit Media, 2009, hlm. 81.
} 
dan Pasal 193 ayat (1) KUHAP maka bentuk dari putusan hakim terhadap terdakwa tindak pidana korupsi dapat berupa putusan bebas dan putusan pemidanaan. ${ }^{22}$

Alat bukti yang sah menurut Pasal 184 KUHAP ialah: Keterangan saksi, Keterangan ahli, Surat, Petunjuk, Keterangan terdakwa. Adapun mengenai tindak pidana korupsi dalam UU No. 20 Tahun 2001 tentang Perubahan Atas UU No. 31 Tahun 1999 tentang Pemberantasan Tindak Pidana Korupsi Pasal 26A ada tambahan mengenai alat bukti yang sah dalam bentuk petunjuk, yaitu: 1 . Alat bukti lain yang berupa informasi yang diucapkan, dikirim, diterima, atau disimpan secara elektronik dengan alat optik atau yang serupa dengan itu; dan 2. Dokumen, yakni setiap rekaman data atau informasi yang dapat dilihat, dibaca, dan atau didengar yang dapat dikeluarkan dengan atau tanpa bantuan suatu sarana, baik yang tertuang di atas kertas, benda fisik apa pun selain kertas, maupun yang terekam secara elektronik, yang berupa tulisan, suara, gambar, peta, rancangan, foto, huruf, tanda, angka, atau perforasi yang memiliki makna. ${ }^{23}$

Menurut penulis pemberian vonis bebas oleh hakim pada Putusan Perkara Nomor: 454/Pid.B/2010/PN.Kdi merupakan sesuatu yang wajar karena sudah sesuai dengan ketentuan peraturan perundang-undangan karena dari proses persidangan yang dilakukan maka hakim menemukan bahwa perbuatan terdakwa tidak memenuhi unsur dakwaan primer, dakwaan subsider dan dakwaan lebih subsider.

Penulis, melihat dalam hal majelis hakim memberikan vonis bebas terhadap terdakwa dari segala dakwaan jaksa seperti disebutkan dalam amar putusannya majelis hakim yang menyatakan: Menyatakan terdakwa Nana Sumarna, S.Pd., M.Kes. tidak terbukti secara sah dan meyakinkan bersalah Melakukan tindak pidana dalam dakwaan Primer, Subsider dan Lebih Subsider; dan Membebaskan terdakwa Nana Sumarna, S.Pd., M.Kes. oleh karena itu dari dakwaan-dakwaan tersebut (Vrijspraak); serta Memulihkan hak terdakwa dalam kemampuan, kedudukan dan harkat serta martabatnya; disebabkan jaksa tidak dapat menghadirkan bukti maupun keterangan yang dapat meyakinkan hakim bahwa terdakwa telah melakukan tindak pidana korupsi.

Putusan Bebas/vrijspraak dalam Perkara Nomor: 454/Pid.B/2010/PN.Kdi oleh hakim terjadi karena tidak terdapatnya alat bukti seperti ditentukan asas minimum pembuktian menurut undang-undang secara negatif sebagaimana dianut oleh KUHAP, pada Pasal 184 (1) Alat bukti yang sah ialah: a. keterangan saksi, b. keterangan ahli, c. surat,

22 P.A.F Lamintang, Dasar-Dasar Hukum Pidana Indonesia, Bandung: Sinar Baru. 2004, hlm. 110.

23 Ibid., hlm. 35. 
d. petunjuk, e. keterangan terdakwa. Sehingga wajar adanya jika hakim memberikan vonis bebas sesuai bunyi pasal 191 KUHAP.

\section{KESIMPULAN}

1. Pembuktian tindak pidana korupsi penyalahgunaan kewenangan pada Putusan Nomor: 454/Pid.B/2010/PN.Kdi. Pembuktian oleh jaksa bahwa perbuatan terdakwa merupakan perbuatan melawan hukum menyalahgunakan kewenangan, serta menguntungkan diri sendiri karena meminta sejumlah uang dalam kegiatan penyerahan sertifikat setelah kegiatan terlaksana merupakan sebuah kekeliruan karena sesuai dengan perjanjian kerja sama yang disepakati oleh pihak UNHALU dan LPMP yang salah satu poinnya memuat Daftar Isian Pelaksanaan Anggaran (DIPA) pada kenyataannya tidak masuk dalam anggaran untuk penyerahan ijazah yang dilaksanakan pada gedung Grand Awani serta biaya legalisasi ijazah dan biaya lainnya. Sehingga wajar adanya perbuatan terdakwa yang mengumumkan pembayaran sejumlah uang untuk kegiatan penyerahan sertifikat dan lain sebagainya bukan merupakan sebuah perbuatan yang belum diatur dalam Peraturan Pemerintah (PP) Nomor: 74 tahun 2008 tentang Guru, untuk itu dakwaan jaksa tidak terbukti secara sah.

2. Ratio decidendi hakim dalam menjatuhkan vonis bebas terhadap terdakwa pada Putusan Nomor: 454/Pid.B/2010/PN.Kdi seperti disebutkan dalam amar putusannya majelis hakim yang menyatakan: "terdakwa Nana Sumarna, S.Pd., M.Kes. tidak terbukti secara sah dan meyakinkan bersalah Melakukan tindak pidana dalam dakwaan Primer, Subsider dan Lebih Subsider; dan Membebaskan terdakwa Nana Sumarna, S.Pd., M.Kes, disebabkan karena majelis hakim dalam pertimbangan yuridis dan non yuridis majelis hakim menerangkan bahwa unsur tindak pidana korupsi seperti unsur menguntungkan diri sendiri, unsur melawan hukum serta unsur merugikan keuangan negara tidak terpenuhi dalam perkara tersebut seperti yang di dakwakan oleh jaksa penuntut umum. 


\section{Daftar Pustaka}

\section{Buku}

Adji, Indriyanto Seno. Korupsi dan Penegakan Hukum, Jakarta: Diadit Media, 2009.

Andrisman, Tri. Hukum Acara Pidana, Lampung: Universitas Lampung, 2010.

Davies, Malcolm. CriminalJustice: An Introduction to The Criminal Justice Systemin England and Wales, London: Pearson Education Limited, 2005.

H, Abdullah. Membangun Gerakan Antikorupsi Dalam Perspektif Pengadilan, Yogyakarta: LP3 UMY, 2011.

Harahap, Krisna. Pemberantasan Korupsi Di Indonesia Jalan Tiada Ujung. Bandung: Grafitri, 2009.

Jeddawi, Murtir. Negara Hukum, Good Governance Dan Korupsi Di Daerah, Yogyakarta: Total Media, 2011.

Lamintang, P.A.F. Dasar-Dasar Hukum Pidana Indonesia. Bandung: Sinar Baru. 2004.

Lamintang, P.A.F. dan Lamintang, Theo. Kejahatan Jabatan dan Kejahatan Jabatan Tertentu Sebagai Tindak Pidana Korupsi. Jakarta: Sinar Grafika, 2009.

Manan, Abdul. Etika Hakim Dalam Penyelenggaraan Peradilan, Jakarta: Kencana Perdana Group, 2008.

Muhammad, Abdulkadir. Etika Profesi Hakim, Bandung: Citra Aditya Bakti, 2007.

Mulyadi, Lilik. Tindak Pidana Korupsi di Indonesia Normatif, Teorits, Praktik dan Masalahnya. Bandung: Alumni, 2011.

Saputra, Nyoman Jaya. Tindak Pidana Korupsi, Kolusi, dan Nepotisme di Indonesia, Semarang: Universitas Diponegoro, 2005.

\section{E- Jurnal}

Wibowo, Edy. "Peranan Hakim dalam Pencegahan dan Pemberantasan Korupsi”. Jurnal Legislasi Indonesia Volume 7 November 4 Desember 2010, Direktorat Jendral Peraturan Perundang-undangan Kementerian Hukum dan Hak Asasi Manusia RI.

\section{Peraturan Perundang-undangan}

Undang-Undang Nomor 1 Tahun 1946 Tentang Kitab Undang-Undang Hukum Pidana.

Undang-Undang Nomor 8 Tahun 1981Tentang Kitab Undang-Undang Hukum Acara Pidana.

Undang-Undang Nomor 31 Tahun 1999 Tentang Pemberantasan Tindak Pidana Korupsi. 
Undang-Undang Nomor 20 Tahun 2001 Tentang Perubahan Atas Undang-Undang Nomor 31 Tahun 1999 Tentang Pemberantasan Tindak Pidana Korupsi. 